\title{
INHIBITION OF LYMPH NODE METASTASIS OF P388 LEUKEMIA BY BESTATIN IN MICE
}

\author{
Takashi Tsuruo, Kuniko Naganuma, Harumi Iida, Takao Yamori, \\ Shigeru Tsukagoshi and Yoshio Sakurai \\ Cancer Chemotherapy Center, Japanese Foundation for Cancer Research, \\ Toshima-ku, Tokyo 170, Japan
}

(Received for publication April 24, 1981)

\begin{abstract}
Bestatin, a chemically defined immunostimulant of low molecular weight, suppressed the gradually-occurring lymph node metastasis of $\mathrm{P} 388$ leukemia in $\mathrm{CDF}_{1}$ mice when administered i.p. at the doses of $1 \sim 30 \mu \mathrm{g} / \mathrm{mouse}$. It could not, however, suppress the established large metastasis of P388 leukemia. Lymph node cells isolated from the mice given bestatin i.p. at 1 and $30 \mu \mathrm{g} /$ mouse showed stronger cytostatic activity against P388 leukemic cells in vitro than those from the untreated mice.
\end{abstract}

Bestatin, a dipeptide [(2S,3R)-3-amino-2-hydroxy-4-phenylbutanoyl]-L-leucine, is a low toxicity immunostimulant recently developed by UMEZAWA et al. ${ }^{1,2)}$. It binds to the cell surface of lymphocytes and macrophages ${ }^{2 \sim 4)}$ and enhances both humoral and cell-mediated immune functions ${ }^{1,2,5 \sim 7)}$. Bestatin possesses antitumor activity and also enhances the antitumor activity of bleomycin and adriamycin ${ }^{8)}$.

In the present study, we examined the inhibitory effect of bestatin on lymph node metastasis of P388 leukemia. In an experimental model of lymph node metastasis using P388 leukemia, the tumor cells metastasize primarily from the inoculation site to the axillary lymph node ${ }^{8)}$. Bestatin could suppress the micrometastasis of tumor cells occurring gradually, but it could not suppress the established large lymph node metastasis.

\section{Materials and Methods}

Animals and Tumor

Adult female $\mathrm{CDF}_{1}$ mice (Charles River Japan Inc., Tokyo, Japan) weighing $20 \sim 23 \mathrm{~g}$ were used in all experiments; DBA/2Cr mice (Simonsen Laboratories Inc., Gilroy Calif., U.S.A.) were the P388 leukemia carriers. P388 leukemia cells were supplied by the Mason Research Institute, Worcester, Mass., U.S.A., under the auspices of the National Cancer Institute, NIH, Bethesda, Md., U.S.A.

Bestatin

Bestatin was provided by Dr. H. Umezawa, Institute of Microbial Chemistry, Shinagawa, Tokyo, Japan.

Evaluation of Antitumor Activity

P388 leukemic cells $\left(1 \times 10^{6}\right)$ suspended in one-tenth $\mathrm{ml}$ of HANKS' balanced salt solution was inoculated i.p. into $\mathrm{CDF}_{1}$ mice. Bestatin was dissolved in $0.15 \mathrm{M} \mathrm{NaCl}$ and administered i.p. on days $1 \sim 9$. The control animals received the vehicle. Antitumor activity was determined by comparing the mean survival time of treated groups $(\mathrm{T})$ with that of control groups $(\mathrm{C})$ and expressed as a percentage $(\mathrm{T} / \mathrm{C} \%)$.

Inhibition of Lymph Node Metastasis

Experimental model system of lymph node metastasis of P388 leukemia was used ${ }^{8)}$. Briefly, P388 leukemic cells $\left(3 \times 10^{5}\right)$ were suspended in $0.05 \mathrm{ml}$ HANKs' balanced salt solution and inoculated s.c. into the right forefootpad of $\mathrm{CDF}_{1}$ mice. As reported previously ${ }^{8)}$, P388 leukemic cells metastasized 
primarily to the right axillary lymph node. Bestatin was administered i.p. at $1 \sim 30 \mu \mathrm{g} /$ mouse daily for $1 \sim 11$ days. The control animals received the vehicle $(0.15 \mathrm{M} \mathrm{NaCl})$. Fifteen mice were used per dosage. Twelve days after tumor inoculation, the mice were killed and the axillary lymph node was removed. The extent of metastasis in the axillary lymph node was estimated by the bioassay method, where the whole axillary lymph node with tumor metastasis was transferred i.p. to normal mice under aseptic conditions. Antimetastatic activity was also expressed by $\mathrm{T} / \mathrm{C}$ values calculated on the basis of the mean survival time of treated to control animals. Alternatively, the number of P388 cells in the axillary lymph node was calculated by the survival time of lymph node recipient mice.

In another experiment, $1 \times 10^{8} \mathrm{P} 388$ leukemic cells were inoculated, and the right forelimb including the original tumor was amputated on day 6 when the metastasis had already been established. Bestatin was given i.p. at $1 \sim 90 \mu \mathrm{g} /$ mouse daily 4 times starting from day 8 . On day 12 , the axillarly lymph node was transferred i.p. to normal mice to estimate the antimetastatic activity of bestatin as described above.

\section{In Vitro Growth Inhibition Assay}

Lymph node cells were assayed for in vitro P388 growth inhibition according to the method described previously ${ }^{9}$. Axillary lymph nodes were removed from mice (10 mice per group) which was given bestatin i.p. at $1 \mu \mathrm{g}$ and $30 \mu \mathrm{g} /$ mouse daily for 11 days. Lymph node was squeezed gently with forceps to release cells into RPMI medium 1640 (Grand Island Biological Co., Grand Island, N.Y., U.S.A.) containing $10 \%$ fetal bovine serum (Grand Island Biological), $20 \mu \mathrm{M}$ 2-mercaptoethanol and kanamycin at $100 \mu \mathrm{g} / \mathrm{ml}^{10)}$. A free cell suspension was prepared by pipetting and the cell suspension was filtered through 4 folds of gauze. The cells were collected by centrifugation at $70 \times g$ for 5 minutes.

The cells $\left(0.3 \sim 1.0 \times 10^{6}\right)$ from lymph node were incubated in $1 \mathrm{ml}$ of the culture medium at $37^{\circ} \mathrm{C}$ in a humidified atomosphere with $5 \% \mathrm{CO}_{2}$ in a Falcon 2054 tube. After 24 hours, $1 \mathrm{ml}$ of the medium containing $2 \times 10^{3} \mathrm{P} 388$ cells was added to the medium and $\mathrm{P} 388$ cells were cultivated at $37^{\circ} \mathrm{C}^{10)}$. On day 3 , an aliquot $(50 \mu \mathrm{l})$ of cell suspension was transferred into fresh culture medium and P388 cells were cultivated for another 3 days. P388 cells were then counted with a Coulter counter ${ }^{10)}$. The growth inhibition was expressed as relative percentage of P388 cell numbers in test and control experiments.

\section{Results}

\section{Antitumor Activity of Bestatin}

Bestatin administered i.p. daily for 9 days did not show any significant antitumor activity against i.p. inoculated P388 leukemia (Table 1). This indicates that bestatin is not a cytotoxic agent against P388 leukemia.

Table 1. Effect of bestatin on the survival time of mice bearing P388 leukemia.

\begin{tabular}{c|c|c}
\hline $\begin{array}{c}\text { Dose } \\
(\mu \mathrm{g} / \text { mouse })\end{array}$ & $\begin{array}{c}\text { MST } \pm \mathrm{SD}^{\mathrm{a}} \\
(\text { days })\end{array}$ & $\begin{array}{c}\mathrm{T} / \mathrm{C} \\
(\%)\end{array}$ \\
\hline 0 & $9.8 \pm 0.4$ & 100 \\
1 & $9.8 \pm 1.0$ & 100 \\
3 & $10.0 \pm 1.3$ & 102 \\
10 & $10.0 \pm 0.6$ & 102 \\
30 & $9.3 \pm 0.5$ & 95 \\
60 & $9.8 \pm 0.8$ & 100 \\
90 & $9.2 \pm 0.8$ & 94 \\
\hline
\end{tabular}

a $\mathrm{MST} \pm \mathrm{SD}$, mean survival time \pm standard deviation. Six mice were used per each group.
Table 2. Inhibition of lymph node metastasis of P388 leukemia by i.p. administered bestatin.

\begin{tabular}{c|c|c|c}
\hline $\begin{array}{c}\text { Dose } \\
(\mu \mathrm{g} / \text { mouse })\end{array}$ & $\begin{array}{c}\text { MST } \pm \mathrm{SD}^{\mathrm{a}} \\
(\text { days })\end{array}$ & $\begin{array}{c}\mathrm{T} / \mathrm{C} \\
(\%)\end{array}$ & $\begin{array}{c}\text { Cell No. } \\
\left(\times 10^{4}\right)\end{array}$ \\
\hline 0 & $10.7 \pm 1.7$ & 100 & 90.0 \\
1 & $14.6 \pm 1.9^{\mathrm{c}}$ & 136 & 0.20 \\
3 & $13.0 \pm 3.4^{\mathrm{d}}$ & 121 & 2.45 \\
10 & $12.8 \pm 1.7^{\mathrm{c}}$ & 120 & 3.30 \\
30 & $12.2 \pm 1.8^{\mathrm{d}}$ & 114 & 8.50 \\
\hline
\end{tabular}

a $\mathrm{MST} \pm \mathrm{SD}$, mean servival time \pm standard deviation. Fifteen mice were used per each group.

b The number of tumor cells in lymph node was estimated by calibration curve ${ }^{8)}$.

c Significant by Student's t-test $(\mathrm{P}<0.05)$.

d Significant by Student's t-test $(\mathrm{P}<0.1)$. 
Table 3. Effect of bestatin on the established lymph node metastasis of P388 leukemia.

\begin{tabular}{c|c|r}
\hline $\begin{array}{c}\text { Dose } \\
(\mu \mathrm{g} / \text { mouse })\end{array}$ & $\begin{array}{c}\text { MST } \pm \mathrm{SD}^{\mathrm{a}} \\
\text { (days) }\end{array}$ & $\begin{array}{c}\mathrm{T} / \mathrm{C} \\
(\%)\end{array}$ \\
\hline 0 & $8.4 \pm 1.1$ & 100 \\
1 & $7.6 \pm 1.5$ & 90 \\
3 & $8.6 \pm 1.9$ & 102 \\
10 & $8.2 \pm 1.3$ & 98 \\
30 & $8.0 \pm 1.4$ & 95 \\
90 & $8.2 \pm 0.4$ & 98 \\
\hline
\end{tabular}

a $\mathrm{MST} \pm \mathrm{SD}$, mean survival time \pm standard diviation. Ten mice were used per each group. Bestatin was given i.p.
Table 4. Growth inhibition of P388 leukemic cells by lymph node cells.

\begin{tabular}{l|cc}
\hline & \multicolumn{2}{|c}{$\begin{array}{c}\text { Growth of P388 } \\
\text { cell (\% of control) } \\
\text { for effector: target } \\
\text { cell ratio }\end{array}$} \\
\hline $\begin{array}{l}\text { Origin of lymph node cells } \\
\text { Bermal mice }\end{array}$ & $150: 1$ & $500: 1$ \\
\hline $1 \mu \mathrm{g} /$ mouse & 85.6 & 79.1 \\
$30 \mu \mathrm{g} /$ mouse & $61.7^{\mathrm{a}}$ & $39.8^{\mathrm{a}, \mathrm{b}}$ \\
Without cells & 74.1 & $40.3^{\mathrm{a}, \mathrm{b}}$ \\
\hline
\end{tabular}

a Significant by Student's t-test $(\mathrm{P}<0.05)$ when compared to the result of experiment without cells.

b Significant by Student's t-test $(\mathrm{P}<0.05)$ when compared to the result of experiment with lymph node cells from normal mice.

\section{Inhibition of Lymph Node Metastasis by Bestatin}

Bestatin, when administered i.p. at $1 \sim 30 \mu \mathrm{g} /$ mouse daily for 11 days, efficiently inhibited the lymph node metastasis of P388 leukemia (Table 2). The most prominent effect was observed at a dose of $1 \mu \mathrm{g} /$ mouse, where the number of the metastatic cells in axillary lymph node was diminished by more than $99.7 \%$. In these experiment, metastasis occurs time-dependently and bestatin was given daily for 11 days.

Bestatin administered i.p. daily for 4 days could not suppress the established tumor-metastasis of P388 leukemia (Table 3); on day 8 , when the first dose of bestatin was given, usually $3.3 \times 10^{4}$ P388 cells metastasized to the axillary lymph node, and bestatin could not suppress this large tumor burden in axillary lymph node.

\section{Growth Inhibition of P388 Cells by Lymph Node Cells Obtained}

from Mice Treated with Bestatin

Lymph node cells from normal mice inhibited the growth of P388 cells by $15 \sim 20 \%$ (Table 4 ). At a lower ratio (150: 1) of lymph node (effector) cells against P388 (target) cells, a significant growth inhibition of target cells by effector cells obtained from bestatin treated mice was observed. At a higher ratio (500: 1), more prominent growth inhibition of target cells was occurred. That is, the growth of target cells was inhibited by $60 \%$ by effector cells obtained from bestatin treated mice, both 1 and $30 \mu \mathrm{g} / \mathrm{mouse}$.

\section{Discussion}

In in vitro experiment, a large number of lymph node cells efficiently inhibited the growth of P388 cells. In in vivo experiment, bestatin efficiently inhibited the metastasis of P388 leukemia when the antibiotic was administered continuously after tumor inoculation. In this model system, P388 cells inoculated into the forefootpad metastasized to the axillary lymph node time-dependently ${ }^{8)}$. We assumed that enough effector cells in the lymph node could attack the small number of P388 cells which were continuously transported from the inoculation site to the axillary lymph node. It has been difficult for non-specific immunomodulator, such as bestatin, to suppress large tumor metastasis. Bestatin could not suppress the established large metastases of P388 leukemia. However, it may be able to inhibit a micrometastasis or metastases which are just occurring by immune mechanisms. 
The mechanism of inhibition of the metastatic growth of P388 cells is not elucidated yet. However, there are several reports on the immunological mechanisms of bestatin. Bestatin was shown to enhance delayed-type hypersensitivity ${ }^{2)}$. It restored delayed-type hypersensitivity reduced by anticancer drug and tumor cell ${ }^{8)}$, and the impaired immune functions of aged mice ${ }^{5)}$. Bestatin binds to the cell surface including lymphocytes and macrophage ${ }^{2 \sim 4)}$, and it showed mitogenic effect on lymphocytes, presumably resulting in the proliferation of $\mathrm{T}$ cells through the activation of macrophages ${ }^{7)}$. Similar mechanisms could also be account for the inhibition of slowly occurring metastasis of P388 leukemia reported here. We are currently investigating the target of bestatin in sub-populations of immune cells in lymph node.

Acknowledgment

We are grateful to Dr. H. UMEZAWA for a generous gift of bestatin.

\section{References}

1) Umezawa, H.; T. Aoyagi, H. Suda, M. Hamada \& T. Takeuchi: Bestatin, an inhibitor of aminopeptidase B, produced by actinomycetes. J. Antibiotics 29: $97 \sim 99,1976$

2) Umezawa, H.; M. Ishizuka, T. Aoyagi \& T. TAKeuchi: Enhancement of delayed-type hypersensitivity by bestatin, an inhibitor of aminopeptidase B and leucine aminopeptidase. J. Antibiotics 29: 857 859, 1976

3) Aoyagi, T.; H. Suda, M. Nagai, K. Ogawa, J. Suzuki, T. Takeuchi \& H. Umezawa: Aminopeptidase activities on the surface of mammalian cells. Biochim. Biophys. Acta 452: 131 143, 1976

4) Umezawa, H.: Recent advances in bioactive microbial secondary metabolites. Jpn. J. Antibiotics 30 (Suppl.): S138 S163, 1977

5) Bruley-Rosset, M.; I. Florentin, N. Kiger, J. Schulz \& G. MathÉ: Restoration of impaired immune functions of aged animals by chronic bestatin treatment. Immunology 38: 75 83, 1979

6) Ishizuka, M.; T. Masuda, N. Kanbayashi, S. Fukasawa, T. Takeuchi, T. Aoyagi \& H. Umezawa: Effect of bestatin on mouse immune system and experimental murine tumors. J. Antibiotics 33: 642 652 1980

7) Ishizuka, M.; J. Sato, Y. Sugiyama, T. Takeuchi \& H. Umezawa: Mitogenic effect of bestatin on lymphocytes. J. Antibiotics 33: 653 662, 1980

8) Tsuruo, T.; K. Naganuma, H. IIdA \& S. Tsukagoshi: Lymph node metastasis and effect of 1- $\beta$-D-arabinofuranosylcytosine, 5-fluorouracil, and their lipophilic derivatives in an experimental model system using P388 leukemia. Cancer Res. 40: 4758 4763, 1980

9) Kataoka, T.; H. Kobayashi \& Y. SakuraI: Potentiation of concanavalin A-bound L1210 vaccine in vivo by chemotherapeutic agents. Cancer Res. 38: 1202 1207, 1978

10) Tsuruo, T.; H. IIdA, S. Tsukagoshi \& Y. SAKuraI: Overcoming of vincristine resistance in P388 leukemia in vivo and in vitro through enhanced cytotoxicity of vincristine and vinblastine by verapamil. Cancer Res. 41: $1967 \sim 1972,1981$ 